\title{
INFLUENCING FACTORS OF CORPORATE RISK DISCLOSURE LEVEL ON BANKING INDUSTRY IN INDONESIA
}

\author{
Harri Baskoro Adiyanto \\ Indonesia Banking School \\ hbaskoro@harribaskoro.com
}

\begin{abstract}
This research wants to examine the effects of Bank Size (CSIZE), Profitability (PROFIT), Public Shares Ownership (ISSUE), Total Number of the Board of Commissioner (BSIZE), Total Meeting of the Board of Commissioner (RPTDEKOM), and Member of Commissioner with background from Banking Supervisory Institution (BIDEKOM) to Corporate Risk Disclosure $(C R D)$. This research analysis method using multiple linear regression analysis models. The result of this research shows that the data has fulfilled the classical assumption, such as: there is no multicollinearity and heteroscedasticity also data has distributed normally. From the regression analysis, found that partially Bank Size, Profitability and Member of Commissioner with Background from Banking Supervisory Institution variable, are significant to Corporate Risk Disclosure, while Public Share Ownership, Total Number of the Board of Commissioner and Total Meeting of the Board of Commissioner are not significant to Corporate Risk Disclosure.
\end{abstract}

\section{Keywords}

Banking; Disclosure; Risk; Governance; Indonesia.

\section{JEL Classification}

M19

\section{Introduction}

Corporate Risk Disclosure (CRD) is an important concern for public, especially investors. It is understandable considering the significance of the information for investors as one of the tools for a careful and precise investment decision. Therefore, corporate risk disclosure should be done in a balanced way, meaning that not only the disclosure of positive information but also negative information especially those related to the company's risk aspect.

In fact, the practice of information disclosure in banking industry in Indonesia is not quite satisfactory. It is evidenced by World Bank's research in 2006 entitled "Bank Disclosure Index: Global Assessment of Bank Disclosure Practices". This study was conducted by computing index composite of banking disclosure in 180 countries since 1994. In this study, measurement was made on disclosure of banking information including assets, liabilities, funding, incomes and risk profiles.

Based on the research, Indonesia's position is ranked 55th out of 177 countries observed by the World Bank. This position is far behind the other Asian countries such as Hong Kong which ranked number 1, Bahrain in $6^{\text {th }}$, Qatar in $8^{\text {th }}$, Japan in $12^{\text {th }}$, UAE in $18^{\text {th }}$ and India in $32^{\text {th }}$ position. Even in Southeast Asian, Indonesia lags behind Thailand which is positioned $29^{\text {th }}$, then Malaysia in $44^{\text {th }}$, followed by Singapore in $45^{\text {th }}$ and Philippines in $48^{\text {th }}$. Compare to Southeast Asia countries, Indonesia is only better than Cambodia, Vietnam, Brunei Darussalam and Laos. 
The results of the research encourage the research on risk disclosure of banks in Indonesia, besides another fact that bank in carrying out its operational activities is more vulnerable to risk compare to other companies. Based on the research background and results of some previous researches, the most appropriate title for this study is: "Influencing Factors of Corporate Risk Disclosure Rate on Banking Industry in Indonesia".

Referring to the aforementioned background, the objectives of this research are as the following:

1. Analysing the effect of bank size, profitability, number of public shareholding, number of commissioners, number of commissioners board meeting, number of commissioner board members with retiree status of the banking supervisor authority, against the level corporate risk disclosure (CRD) in Indonesian Banking industry.

2. Analysing the effect bank size, profitability, number of public shareholding, number of commissioners, number of commissioners board meeting, number of commissioner board members with retiree status of the banking supervisor authority, against the level corporate risk disclosure (CRD) in Indonesian Banking industry simultaneously.

This research is expected to be useful for stakeholders to help them obtaining the necessary information to understand risk profile and risk management. It is also attributed for company to be used as bank management reference, in this case the board of directors and senior management, in compiling annual report transparently which include any bank activities to parties related to the company/stakeholders. Furthermore, for Bank Indonesia or the Financial Services Authority (OJK), the results of this study is expected to be used as a consideration in formulating regulations in order to improve the effectiveness of company management in presenting annual report as a form of risk disclosure and ensuring stakeholders being accurately informed by company risk.

\section{Theoretical Analysis}

1) Good Corporate Governance Theory

Good Corporate Governance (GCG) was first introduced in 1992. At that time, Cadbury Committee in United Kingdom published a report entitled "The Financial Aspects of Corporate Governance" or better known as Cadbury Report. Since then, Cadbury Report has become the basis for the implementation of Good Corporate Governance Company in United Kingdom even to various other countries.

Corporate Governance is defined by Sir Adrian Cadbury (Mallin 2004, 3) as: "the whole system of controls, both financial and otherwise, by which a company is directed and controlled." While the OECD in 1999 defines it as:

"a set of relationships between a company's board, its shareholders and other stakeholders. It also provides the structure through which the objectives of the company are set, and the means of attaining those objectives, and monitoring performance are determined."

Daniri $(2014,21)$ defines GCG as a pattern of relationships (structure), system and processes that direct the company's organs (Board of Directors, Board of Commissioners and General Meeting of Shareholders (GMS)) that provide added value to the company on an ongoing basis, with due regard the interests of the stakeholders, based on prevailing laws and regulations.

\section{2) Risk Disclosure Theory}

Disclosure is the dissemination of material information to public in which the contents of an evaluation of the business activities of a company, in this case is bank. 
According to Idroes $(2011,234)$ Pillar 3 Basel II sets out the disclosure requirement that enable market participants to assess key information on risk coverage, capital, risk exposure, risk measurement process and bank capital adequacy.

Risk disclosure is important because it helps stakeholders in getting the information needed to understand the risk profile and risk management. Risk disclosure is also useful for risk monitoring and detecting potential problems to encourage early action to prevent it (Linsley and Shrives 2006, 388).

There have been several studies on corporate risk disclosure. "The Extend of Disclosure in Annual Reports of Banking Companies: The Case of India" (Hossain 2008) shows that bank size, profitability, composition of commissioner board and market discipline significantly influence the level of disclosure. Results of this study is in line with research by Elzahar and Hussainey (2012), "Determinants of Narrative Risk Disclosures in UK Interim Reports". The results of this study show that firm size and industry type influence the level of disclosure. In accordance with the results of these studies, researches by Juhmani (2013), Abdallah and Hassan (2014), AlShammari (2014) and Linsley and Shrives (2006) show that firm size significantly influences the level of disclosure.

The uniqueness of this study compare with previous studies is the addition of variable: commissioner board members with retiree status of the banking supervisor authority to replace leverage variable. Variable replacement is conducted because although leverage positively affects corporate risk disclosure, operational definition of leverage variable is less appropriate to be implemented in banking industry. Liabilities in bank balance are mostly third-party fund (savings) as bank obligation/ debt.

Based on the above consideration, this study measures the influences of bank size, profitability, number of public shareholdings, number of commissioner board members, number of commissioner board meeting and commissioner board members with retiree status of banking supervisor authority.

The developed hypotheses are the following:

H1: Bank Size significantly and positively influences the level of risk disclosure in Indonesian Banking industry.

H2: Company Profitability significantly and positively influences the level of risk disclosure in Indonesian Banking industry.

H3: Public shareholding significantly and positively influences the level of risk disclosure in Indonesian Banking industry.

H4: Number of commissioner board member significantly and positively influence the level of risk disclosure in Indonesian Banking industry.

H5: Number of commissioner board meeting significantly and positively influence the level of risk disclosure in Indonesian Banking industry.

H6: Commissioner board members with retiree status of banking supervisor authority significantly influence the level of risk disclosure in Indonesian Banking industry.

H7: Company size, profitability, public shareholdings, number of commissioner board member, number of commissioner board meeting and Commissioner board members with retiree status of banking supervisor authority, simultaneously affects the level of risk disclosure in Indonesian Banking industry.

\section{Research Method}

Population of the current study includes all conventional commercial banks in Indonesia enlisted by Bank Indonesia and Indonesia Stock Exchange that have go public (open) and have issued Annual Report in 2012 and 2013. The number of commercial banks in Indonesia registered in Bank Indonesia until December 2014 
was 120 Bank, consisting of 109 conventional commercial banks and 11 sharia banks. Among the 109 conventional commercial banks, 39 of them have go public and are listed on Indonesia Stock Exchange

Table 1 Banks Enlisted as Research Object

\begin{tabular}{|c|c|c|}
\hline No & Information & $\begin{array}{c}\text { Research } \\
\text { Object }\end{array}$ \\
\hline 1 & Go Public Banks in Indonesia & 39 \\
\hline \multirow[t]{2}{*}{2} & Go Public Sharia Banks in Indonesia & (1) \\
\hline & & 38 \\
\hline \multirow[t]{2}{*}{3} & Conventional IPO bank after 2013 & (3) \\
\hline & & 35 \\
\hline 4 & $\begin{array}{l}\text { Banks enlisted in IDX but suspended } \\
\text { in } 2012 \text { and } 2013\end{array}$ & (1) \\
\hline & Tota & 34 \\
\hline
\end{tabular}

Source: Processed data from various sources (www.idx.co.id)

The analysis model used in this research is multiple linear regression analysis model. This model is intended to test the extent and how the direction of independent variables affects the dependent variable. Multiple regression equation for testing hypothesis in this research is:

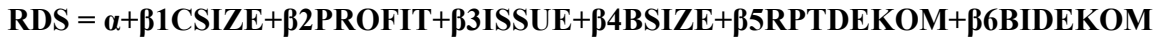

Where:

RDS

CSIZE

PROFIT

ISSUE

BSIZE

RPTDEKOM

BIDEKOM

: Risk Disclosure Score

: Bank Size (Total Asset)

: Profitability

: Number of Public Share

: Number of Commissioner Board Member

: Number of Commissioner Board Meeting

A

: Commissioner board members with retiree status of banking supervisor authority

$\beta 1, \beta 2, \beta 3, \beta 4, \beta 5, \beta 6 \quad$ : $\quad$ Regression Coefficient 
Table 2 Banks Chosen as Research Object

\begin{tabular}{|c|l|c|c|}
\hline No. & \multicolumn{1}{|c|}{ Bank Name } & Code & $\begin{array}{c}\text { Listing } \\
\text { Year }\end{array}$ \\
\hline 1 & Pan Indonesia Bank, Tbk & PNBN & 1982 \\
\hline 2 & Bank Danamon Indonesia,Tbk & BDMN & 1989 \\
\hline 3 & Bank CIMB Niaga, Tbk & BNGA & 1989 \\
\hline 4 & Bank Internasional Indonesia, Tbk & BNII & 1989 \\
\hline 5 & Bank Permata Tbk & BNLI & 1990 \\
\hline 6 & Bank Artha Graha Internasional, Tbk & INPC & 1990 \\
\hline 7 & Bank OCBC NISP, Tbk & NISP & 1994 \\
\hline 8 & Bank Negara Indonesia (Persero), Tbk & BBNI & 1996 \\
\hline 9 & Bank Mayapada Internasional, Tbk & MAYA & 1997 \\
\hline 10 & Bank Victoria Internasional, Tbk & BVIC & 1999 \\
\hline 11 & Bank Bumi Arta Tbk & BNBA & 1999 \\
\hline 12 & Bank Central Asia, Tbk & BBCA & 2000 \\
\hline 13 & Bank Mega, Tbk & MEGA & 2000 \\
\hline 14 & Bank Nusantara Parahyangan, Tbk & BBNP & 2001 \\
\hline 15 & Bank Pundi Indonesia, Tbk & BEKS & 2001 \\
\hline 16 & Bank QNB Kesawan, Tbk & BKSW & 2002 \\
\hline 17 & Bank ICB Bumiputera Indonesia, Tbk & BABP & 2002 \\
\hline 18 & Bank of India Indonesia, Tbk & BSWD & 2002 \\
\hline 19 & Bank Rakyat Indonesia (Persero), Tbk & BBRI & 2003 \\
\hline 20 & Bank Mandiri (Persero), Tbk & BMRI & 2003 \\
\hline 21 & Bank Rakyat Indonesia Agroniaga, Tbk & AGRO & 2003 \\
\hline 22 & Bank Bukopin, Tbk & BBKP & 2006 \\
\hline 23 & Bank Himpunan Saudara 1906, Tbk & SDRA & 2006 \\
\hline 24 & Bank Windu Kentjana Internasional, Tbk. & MCOR & 2007 \\
\hline 25 & Bank Capital Indonesia Tbk & BACA & 2007 \\
\hline 26 & Bank Tabungan Pensiunan Nasional, Tbk & BTPN & 2008 \\
\hline 27 & Bank Ekononomi Raharja. Tbk & BAEK & 2008 \\
\hline 28 & Bank Tabungan Negara (Persero), Tbk & BBTN & 2009 \\
\hline 29 & Bank Jabar Banten Tbk & BJBR & 2010 \\
\hline 30 & Bank Sinarmas, Tbk & BSIM & 2010 \\
\hline 31 & BPD Jatim Tbk & 2012 \\
\hline 32 & Bank National Nobu Tbk & 2013 \\
\hline 33 & Bank Mestika Dharma Tbk & 2013 \\
\hline 34 & Bank Mitraniaga Tbk & 2013 \\
\hline & & NAGA & \\
\hline
\end{tabular}




\section{Result and Analysis}

Table 3 Descriptive Analysis

Statistics Descriptive
\begin{tabular}{|l|r|r|r|r|r|}
\hline & N & \multicolumn{1}{c|}{ Min. } & \multicolumn{1}{c|}{ Max. } & \multicolumn{1}{c|}{ Mean } & Std. Deviation \\
\hline ASSET & 68 & 1048.15 & 733099.76 & 105400.2 & 170083.31358 \\
ROA & 68 & -.01 & .05 & .0219 & .01340 \\
SHARE & 68 & .00 & .51 & .2261 & .16017 \\
COMMISSIONER & 68 & 2.00 & 9.00 & 4.9853 & 1.80788 \\
MEETING & 67 & 4.00 & 79.00 & 17.7761 & 16.96326 \\
BI & 68 & .00 & 1.00 & .2353 & .42734 \\
RDS & 68 & 23.53 & 100.00 & 80.7957 & 17.88342 \\
Valid N (listwise) & 67 & & & & \\
\hline
\end{tabular}

Based on the calculation in Table 3, the minimum value of size bank variable is 1048.15 and the maximum value is 733099,766 with average value of 105400,2 and standard deviation of 170083,313 . Minimum value for profitability variable is -0.01 and the maximum value is 0.05 with average value of 0.02 and standard deviation of 0.013 . Minimum value for public share ownership variable is 0.00 and the maximum value is 0.51 with average value 0.22 and standard deviation of 0.160 . Minimum value for number of commissioner board member is 2 and the maximum value is 9 with average value of 4.98 with standard deviation of 1.807 . Minimum value for number of commissioner board meeting variable is 4 and the maximum value is 79 with average value of 17.77 and standard deviation of 16.963. Minimum value for Commissioner board members with retiree status of banking supervisor authority variable is 0.00 and maximum value of 1 and its average value of 0.23 with a standard deviation of 0.427 . The minimum value for Risk Disclosure Score (RDS) variable is 23.53 and the maximum value is 100 with average value of 80,79 and standard deviation of 17,883 .

\section{Table 4 Research Result}

\begin{tabular}{|c|c|c|c|c|c|c|}
\hline \multicolumn{7}{|c|}{ Coefficients } \\
\hline \multirow{2}{*}{\multicolumn{2}{|c|}{ Model }} & \multicolumn{2}{|c|}{$\begin{array}{l}\text { Unstandardized } \\
\text { Coefficients }\end{array}$} & \multirow{2}{*}{$\begin{array}{c}\begin{array}{c}\text { Standardized } \\
\text { Coefficients }\end{array} \\
\text { Beta }\end{array}$} & \multirow[b]{2}{*}{$t$} & \multirow[b]{2}{*}{ Sig. } \\
\hline & & B & Std. Error & & & \\
\hline \multirow[t]{7}{*}{1} & (Constant) & 72.799 & 7.002 & & 10.397 & .000 \\
\hline & ASSET & 3.37E-005 & .000 & .339 & 2.164 & .034 \\
\hline & $\mathrm{ROA}$ & -384.614 & 166.087 & -.292 & -2.316 & .024 \\
\hline & SAHAM & 18.629 & 13.214 & .176 & 1.410 & .164 \\
\hline & KOMISARIS & 1.438 & 1.256 & .154 & 1.145 & .257 \\
\hline & RAPAT & .241 & .135 & .241 & 1.783 & .080 \\
\hline & $\mathrm{BI}$ & -9.989 & 4.625 & -.253 & -2.160 & .035 \\
\hline
\end{tabular}

a. Dependent Variable: RDS

Based on the details in Table 4, the following results are obtained:

1. Bank Size variable (CSIZE) obtained t count value of 2.164. Since t count $(2,164)$ $>t$ table (1.99), then Ho is rejected. Therefore, it can be concluded that Size Bank (CSIZE) partially has significant influence on Level of Corporate Risk Disclosure.

2. Profitability variable (PROFIT) obtained t count value of 2.316. Since t count $(2,316)>\mathrm{t}$ table $(1.99)$ then Ho is rejected. Therefore, it can be concluded that 
Profitability (PROFIT) partially has a significant influence on Level of Corporate Risk Disclosure.

3. Number of Share Ownership variable (ISSUE) obtained t value of 1.410. Since $t$ count $(1,410)<\mathrm{t}$ table $(1,99)$ then Ho is accepted. Therefore, it can be concluded that Number of Share Ownership (ISSUE) partially has no significant effect to Level of Corporate Risk Disclosure.

4. Number of Commissioner Members variable (BSIZE) obtained t value of 1.145. Since t count $(1.145)<\mathrm{t}$ table $(1.99)$ then Ho is accepted. Therefore, it can be concluded that Number of Commissioner Members (BSIZE) partially has no significant influence Level of Corporate Risk Disclosure.

5. Number of Commissioner Board Meeting variable (RPTDEKOM) obtained $\mathrm{t}$ value of 1,783 . Since $t$ count $(1.783)<t$ table (1.99) then Ho is accepted. Therefore, it can be concluded that Number of Commissioner Board Meeting (RPTDEKOM) partially has no significant effect to Level of Corporate Risk Disclosure.

6. Commissioner board members with retiree status of banking supervisor authority variable (BIDEKOM) obtained value of $t$ count of 2,159. Since $t$ count $(2.159)>t$ table (1.99) then Ho is rejected. Therefore, it can be concluded that Commissioner Background (BIDEKOM) partially has a significant influence on Level of Corporate Risk Disclosure.

Table 5 Determination Coefficient

\begin{tabular}{|c|c|c|c|c|}
\hline \multicolumn{5}{|c|}{ Mode I Summary } \\
\hline Model & $\mathrm{R}$ & R Square & $\begin{array}{l}\text { Adjusted } \\
\text { R Square }\end{array}$ & $\begin{array}{l}\text { Std. Error of } \\
\text { the Estimate }\end{array}$ \\
\hline 1 & $.592^{\mathrm{a}}$ & .350 & .285 & 14.36461 \\
\hline
\end{tabular}

Based on the output of SPSS software above, obtained the value of correlation coefficient $(\mathrm{R})$ of 0,592 . The adjusted determination coefficient of $28.5 \%$ indicates that contribution of bank size, profitability, number of public shareholdings, number of commissioner board members, number of commissioner board meetings and commissioner member with retiree status of banking supervisor authority against level of Corporate Risk Disclosure is $28.5 \%$, while the rest $71,5 \%$ is the contribution of other variable.

The discussion of research result is described as follows:

\section{Influence of bank size to risk disclosure level.}

The first hypothesis proposed in this study is that bank size has significant and positive influence on the level of risk disclosure in Indonesian banking industry. This study obtained regression coefficient value for firm size variable of $3,37 \times 10^{-05}$ with significance value of 0,034 , where this value is significant at 0.05 significance level because it is smaller than 0.05 . Thus, the first hypothesis that bank size has significant and positive influence on the level of risk disclosure can be accepted.

This result is in accordance with research by Linsley and Shrives (2006), Hossain (2008), Elzahar and Hussainey (2012), Juhmani (2013), Abdallah and Hasan (2014), and Al-Shammari (2014) which state that firm size influences risk disclosure level. 


\section{Influence of profitability to risk disclosure level.}

The second hypothesis proposed in this study is that profitability has significant and positive influence to the of risk disclosure level in Indonesian bank industry. This study obtained regression coefficient value for corporate profitability variable of -384.6 with significance value of 0.024 , this value is significant at 0.05 significance level because it is smaller than 0.05 .

Based on existing empirical data and from the results obtained, this study shows that the fluctuation of corporate profitability affect the risk disclosure level. This study shows that bank conventional with Tbk (Go Public) status and high profitability have high level of risk disclosure. This result is in accordance with research by Hossain (2008) and Al-Moataz and Hussainey (2012) which state that company profitability variable influences risk disclosure level.

\section{Influence of public shareholding to risk disclosure level.}

The third hypothesis proposed in this study is that the amount of public share ownership has significant and positive influence to risk disclosure level in Indonesian Banking industry. This study obtained regression coefficient value for public shareholder variable of 18,629 with significance value of 0.164 , where this value is insignificant at 0.05 significance level because it is greater than 0.05 . Thus the third hypothesis that public shareholding significantly influences risk disclosure level is not acceptable.

This finding is not in line with the results of research by Horing and Grundl (2011) which states that cross-listing and proprietary dissemination are associated with risk disclosure level.

\section{Influence of number of commissioner board members to risk disclosure level.}

The fourth hypothesis proposed in this study is that number of commissioner board members has significant and positive influence on risk disclosure level. This study obtained regression coefficient value for number of commissioner board members variable is 1.438 with significance value of 0.257 , where this value is insignificant at 0.05 significance level because it is greater than 0.05 . Thus the fourth hypothesis which states that number of commissioner board members has significant influence on the level of risk disclosure is not acceptable.

This finding is not in line with the results of research by Suhardjanto et al. (2012), Amran et al. (2010), Al-Janadi (2013), Al-Shammari (2014) and Akhtaruddin et al (2014). However, it is in accordance with the results of Elzahar and Hussainey (2012) which states that number of commissioner board members has no effect to risk disclosure level.

\section{Influence of number of commissioner board meeting to risk disclosure level.}

The fifth hypothesis proposed in this study is that the number of commissioner board meeting has significant and positive influence on disclosure risk level. This study obtained regression coefficient value for number of commissioner board meeting variable of 0.241 with a significance value of 0.080 , where this value is insignificant at 0.05 significance level because it is greater than 0.05 . Therefore, the fifth hypothesis which states that the number of commissioner board meeting variable significantly influence risk disclosure level cannot be accepted.

This finding is not in accordance with results of research by Suhardjanto and Dewi (2011)and Suhardjanto et al (2012) which state that the number of commissioner board meeting influences risk disclosure level. 
6. Influence of commissioner member with retiree status of banking supervisor authority to risk disclosure level.

The sixth hypothesis proposed in this study is that commissioner member with retiree status of banking supervisor authority influences risk disclosure level. This study obtained regression coefficient value for commissioner member with retiree status of banking supervisor authority variable at -9.989 with significance value of 0.035 , where this value is significant at 0.05 significance level because it is less than 0.05 . Thus the sixth hypothesis which states that the existence of commissioner member with retiree status of banking supervisor authority influence risk disclosure level is inferred to have a significant effect.

\section{Influence of all independent variables on risk disclosure level simultaneously.}

The seventh hypothesis proposed in this study is that bank size, profitability, number of public shareholdings, number of commissioner board members, number of commissioner board meeting, and commissioner member with retiree status of banking supervisor authority are simultaneously affect the level of corporate risk disclosure (CRD) in Indonesian Banking industry.

This study obtained F count value of 5.384 . Then since $F$ count value $(5,384)>F$ table (2.25) and the significance value is $0.000<0.05$, it can be concluded there is a significant influence between bank size, profitability, number of public shareholdings, number of commissioner board members, number of commissioner board meeting, and commissioner member with retiree status of banking supervisor authority to corporate risk disclosure level (CRD) simultaneously. Thus, independent variables in conventional banking with Tbk (Go Public) status in this study mutually influence each other on risk disclosure level.

\section{Conclusion and Implication}

Here are some conclusions that can be drawn from this research:

1. Among the six independent variables: between bank size, profitability, number of public shareholdings, number of commissioner board members, number of commissioner board meeting, and commissioner member with retiree status of banking supervisor authority, there are three variables with significant influence on level of corporate risk disclosure (CRD) in banking industry.

a. Bank size, which in this study inferred from conventional banks with Tbk (Go Public) status. Greater the total assets owned, the better risk disclosure level score to the public. This is due to the obligation that bank should not only showing its performance to the public but also presenting risk management ability.

b. Profitability in this study indicates a significant influence on risk disclosure level. Based on the existing empirical data and results obtained, the fluctuation of company profitability influence the level of risk disclosure.

c. Commissioner with retiree status of banking supervisor authority is new independent variable that did not exist in previous studies. The result of this study shows that commissioner with retiree status of banking supervisor authority has a significant influence to risk disclosure level of a bank.

2. From the result of $\mathrm{t}$ test by considering the value of significance, it can be concluded that the most significant variable to corporate risk disclosure (CRD) level is profitability with $t$ significance value of 0.024 . While the independent variable with the least effect on corporate risk disclosure (CRD) level is the number of commissioner board member with significance value of 0.257 . From the result of $\mathrm{F}$ test, it is proved that the significance value of $\mathrm{F}$ is 0,000 smaller 
than pre-determined significance value of 0.05 . Thus all independent variables in this study simultaneously have a significant effect on corporate risk disclosure (CRD) level.

From the research result, it can be observed that the independent variables that significantly influence risk disclosure level are bank size, profitability and commissioner with retiree status of banking supervisor authority. Therefore, it is recommended for supervisor authority of banking and capital market to observe and scrutinize those three factors, considering their significant effects on risk disclosure level. It should be conducted to align that bank supervision and control policy.

For banking management, these three factors should be considered regarding the fact that great assets and profitability as well as the existence of commissioner with retiree status of banking supervisor authority have a significant effect on bank risk disclosure.

While the variables that do not affect risk disclosure level include share ownership, number of commissioner board members and number of commissioner board meeting. The number of those three variables has no significant effect on risk disclosure level. Nevertheless, these variables are still needed to be considered because these independent variables are simultaneously affecting each other to the level of risk disclosure.

\section{References}

Abdallah, Abed Al-Nasser dan Mostafa Kamal Hassan (2014), The Determinants of Corporate Risk Disclosure in the Gulf Cooperative Council (GCC) Countries, Paper presented on: the BAFA 2014 Annual Conference, London School of Economics and Political Science, April 14-16, 2014. UK.

Abeysekera, Indra (2010), The Influence of Board Size on Intellectual Capital Disclosure by Kenyan Listed Firms, Journal of Intellectual Capital 11 (4) hlm.504-518, available at http://ro.uow.edu.au/cgi/viewcontent.cgi?article= $1803 \&$ context $=$ commpapers.

Adamu, Musa Uba, (2013), The Need for Corporate Risk Disclosure in the Nigerian Listed Companies Annual Reports, IOSR Journal of Economics and Finance $(I O S R-J E F)$, Vol I Issue 6, available at http://www.iosrjournals.org/iosrjef/papers/vol1-issue6/D0161521.pdf?id=7858.

Adamu, Musa Uba (2013), Risk Reporting: A Study of Risk Disclosures in the Annual Reports of Listed Companies in Nigeria, Research Journal of Finance and Accounting Vol. 4 No. 16, available at http://www.iiste.org/Journals/ index.php/RJFA/article/download/8294/8654.

Ahmed, Anwer S, Anne Beatty and Bruce Bettinghaus (1999), Evidence on the Efficacy of Market Risk Disclosures by Commercial Banks, available at http://papers.ssrn.com/sol3/papers.cfm?abstract_id=164729.

Akhtaruddin, Mohamed, Monirul Alam Hossain, Mahmud Hossain and Lee Yao (2009). Corporate Governance and Voluntary Disclosure in Corporate Annual Reports of Malaysian Listed Firms. JAMAR Vol. 7 - Number 1 - 2009, available at http://www.monirulhossain.com/images/papers/articles_already_ published/articles_already_published_11.pdf.

Al-Janadi, Yaseen., Rashidah Abdul Rahman and Normah Haj Omar (2013), Corporate Governance Mechanism and Voluntary Disclosure in Saudi Arabia. Research Journal of Finance and Accounting Vol. 4 No. 4, 2013 available at https://www.researchgate.net/publication/255715400_Corporate_Governance_ Mechanisms_and_Voluntary_Disclosure_in_Saudi_Arabia.

Ali, Mazurina Mohd and Dennis Taylor (2014), Corporate Risk Disclosure in Malaysia: The Influence of Predispositions of Chief Executive Officers and 
Chairs of Audit Committee, Research Journal of Finance and Accounting Vol. 5 No. 2, 2014, available at http://www.academia.edu/5948749/Corporate_ Risk_Disclosure_in_Malaysia_The_Influence_of_Pre-_dispositions_of_Chief_ Executive_Officers_and_Chairs_of_Audit_Committee.

Ali, Mazurina Mohd and Dennis Taylor (2014), Content Analysis of Corporate Risk Disclosure in Malaysia, 4th Annual International Conference on Accounting and Finance (AF 2014), available at https://www.researchgate.net/publication/ 262603739_Content_analysis_of_corporate_risk_disclosure_in_Malaysia.

Al-Moataz, Ehsan and Khaled Hussainey (2012), Determinant of Corporate Governance Disclosure in Saudi Companies, Journal of Economics and Management, available at http://alqashi.com/wp/wp-content/uploads/2012/02/ Determinants-of-Corporate-Governance-Disclosure-in-Saudi-Companies.pdf.

Al-Shammari, Bader (2014), An Investigation of the Impact of Corporate Governance Mechanisms on Level of Corporate Risk Disclosure: Evidence from Kuwait, International Journal of Business and Social Research (IJBSR), available at http://thejournalofbusiness.org/index.php/site/article/view/491.

Al-Shammari, Bader (2014), Kuwait Corporate Characteristics and Level of Risk Disclosure: A Content Analysis Approach, Journal of Contemporary Issues in Business Research Vol 3, Issue No. 3, 2014, available at http://jcibr.webs.com/ archives/volume-2014/Article-V-3-N-3-012014JCIBR0047.pdf.

Amran, Azlan, M.S. Ishak, A.H. Zulkafli and M. Nejati (2010), Board Structure and Extent of Corporate Governance Statement, International Journal Managerial and Financial Accounting Vol. 2 No. 4, 2010, available at https://www.researchgate.net/publication/227441168_Board_structure_and_ex tent_of_corporate_governance_statement.

Amran, Azlan, Abdul Manaf Rosli Bin and Bin Che Haat Mohd Hassan (2009), Risk reporting an exploratory study on risk management disclosure in Malaysian annual reports, Managerial Auditing Journal Vol. 24, No. 1, 2009, available at https://www.researchgate.net/publication/227429821_Risk_reporting_An_expl oratory_study_on_risk_management_disclosure_in_Malaysian_annual_reports

Andres, Pablo de and Eleuterio Vallelado (2008), Corporate Governance in Banking: The Role of the Board of Directors, Journal of Banking \& Finance 32 (2008), available at http://www.sciencedirect.com/science/article/pii/ S0378426608001003.

Bank for International Settlements (2012), Core Principles for Effective Banking Supervision, Basel, Switzerland, Bank for International Settlements, available at http://www.bis.org/publ/bcbs213.pdf.

Barth, James R., Gerard Caprio Jr., and Ross Levine (2012), Bank Regulation and Supervision: what works best?, Journal of Financial Intermediation 13 (2004) hlm.205-248, available at https://www.bis.org/bcbs/events/b2ealev.pdf.

Barth, James R., Jie Gan and Daniel E. Nolle (2004), Global Banking Regulation \& Supervision: What Are the Issues and What Are the Practices? (with Barth and Nolle), in Focus on Financial Institutions and Services, Nova Science Publisher, available at https://www.researchgate.net/publication/255605349_ Global_Banking_Regulation_Supervision_What_Are_the_Issues_and_What_ Are the_Practices.

Botosan, Christine A (1997), Disclosure Level and the Cost of Equity Capital American Accounting Association, the Accounting Review Vol. 72, No. 3 (Jul 1997), available at http://papers.ssrn.com/sol3/papers.cfm?abstract_id=2926.

Cooper, Donal R and Pamela S.Schindler (2011), Business Research Methods. Singapore, McGrawHill. 
Damak-Ayadi, Salma dan Yvon Pesqueux (2005), Stakeholder Theory in Perspective, Corporate Governance, Wiley-Blackwell, 2005, 5 (2), hlm.5-21, available at https://halshs.archives-ouvertes.fr/halshs-00154129.

Daniri, Mas Achmad (2014). Lead By GCG. Jakarta: Gagas Bisnis Indonesia.

Davis, E. Philip and Ugochi Obasi (2009), The Effectiveness of Banking Supervision. London: Brunel University Department of Economics and Finance, available at https://www.brunel.ac.uk/_data/assets/pdf_file/0020/82118/0927.pdf.

Donaldson, Thomas and Lee E. Preston (1995), The Stakeholder Theory of the Corporation: Concepts, Evidence, and Implications, The Academy of Management Review, Vol. 20, No. 1 (Jan 1995), hlm. 65-91, available at http://www.jstor.org/stable/258887.

Elzahar, Hany dan Khaled Hussainey (2012), Determinants of Narrative Risk Disclosures in UK Interim Reports, The Journal of Risk Finance 02/2012; 13(2):133-147, available at http://www.emeraldinsight.com/doi/abs/10.1108/ 15265941211203189.

Fontaine, Charles, Antoine Haarman and Stefan Schmid (2006). The Stakeholder Theory, available at http://www.martonomily.com/sites/default/files/attach/ Stakeholders\%20theory.pdf.

Freeman, R. Edward and John McVea (2001), A Stakeholder Approach to Strategic Management, Darden Business School Working Paper No. 01-02, available http://ssrn.com/abstract=263511 or http://dx.doi.org/ 10.2139/ ssrn.263511.

Gitman, Lawrence J. and Chad J. Zutter (2012), Principles of Managerial Finance 13th ed. Boston: The Prentice Hall series in finance.

Gregory, Holly J (2001), International Comparison of Corporate Governance Guidelines and Codes Of Best Practice Investor Viewpoints, New York: Weil, Gotshal \& Manges LLP - Egon Zehnder, available at http://www.ecgi.org/ codes/documents/international_comparison_investor_viewpoints.pdf.

Group of Thirty (2008), The structure of Financial Supervision: Approaches and Challenges in a Global Marketplace, Washington: The Group of Thirty, available at http://group30.org/images/uploads/publications/G30_Structure FinancialSupervision2008.pdf.

Hassan, Mostafa Kamal (2013), Corporate Governance Characteristics and Voluntary Disclosure: The Case of UAE Listed Corporations, Bangkok: The 2013 IBEA, International Conference on Business, Economics, and Accounting $20-23$ March 2013.

Helbok, Gunther and Christian Wagner (2006), Determinants of Operational Risk Reporting in the Banking Industry, available at http://papers.ssrn.com/sol3/ papers.cfm?abstract_id $=425720$.

Ho, Simon S.M. and Kar Shun Wong (2001), A Study of the Relationship between Corporate Governance Structures and the Extent of Voluntary Disclosure, Journal of International Accounting, Auditing \& Taxation 10 (2001) hlm.139156, https://www.researchgate.net/publication/247245853_A_Study_of_the_ Relationship_Between_Corporate_Governance_Structures_and_the_Extent_of _Voluntary_Disclosure.

Horring, Dirk dan Helmut Grundl (2011), Investigating Risk Disclosure Practices in the European Insurance Industry, available at https://www.researchgate.net/ publication/227361940_Investigating_Risk_Disclosure_Practices_in_the_Euro pean_Insurance_Industry.

Hossain, Mohammed (2008), The Extent of Disclosure in Annual Reports of Banking Companies: The Case of India, European Journal of Scientific Research Vol. 23 no. 4 (2008), hlm.660-681, available at http://qspace.qu.edu.qa/bitstream/ handle/10576/10429/ejsr_23_4_15.pdf?sequence=1. 
Htay, Sheila Nu Nu, Ridzwana Mohd Said and Syed Ahmed Salman (2013), Impact of Corporate Governance on Disclosure Quality: empirical Evidence from Listed Banks in Malaysia, International Journal of Economics and Management 7 (2): hlm. 242-279, available at https://www.researchgate.net/ publication/286174342_Impact_of_corporate_governance_on_disclosure_qual ity_Empirical_evidence_from_listed_banks_in_Malaysia.

Huang, Rocco (2006), Bank Disclosure Index: Global Assessment of Bank Disclosure Practices, Washington: World Bank, available at https://www.researchgate.net/ publication/256002059_Bank_Disclosure_Index_Global_Assessment_of_Ban k_Disclosure_Practices.

Idroes, Ferry. N (2011), Manajemen Risiko Perbankan: Pemahaman Pendekatan 3 Pilar Kesepakatan Basel II Terkait Aplikasi Regulasi dan Pelaksanaannya di Indonesia, Jakarta: Rajawali Pers.

Idroes, Ferry. N and Sugiarto (2006), Manajemen Risiko Perbankan: Dalam Konteks Kesepakatan Basel dan Peraturan Bank Indonesia, Yogyakarta: Graha Ilmu.

Jensen, Michael C., and William H. Meckling (1976), Theory of the Firm: Managerial Behavior, Agency Costs and Ownership Structure, Journal of Financial Economics, October, 1976, V. 3, No. 4, hlm.305-360, available at http://papers.ssrn.com/sol3/papers.cfm?abstract_id=94043.

Juhmani, Omar (2013), Ownership Structure and Corporate Voluntary Disclosure: Evidence from Bahrain, International Journal of Accounting and Financial Reporting Vol. 3, No. 2, available at https://www.researchgate.net/publication/ 263655861_Ownership_Structure_and_Corporate_Voluntary_Disclosure_Evid ence_from_Bahrain.

Krivoy, Ruth de (2000), Reforming Bank Supervision In Developing Countries. Conference Series 44 Building an Infrastructure for Financial Stability, Boston: the Federal Reserve Bank of Boston, available at http://www.bostonfed.org/economic/conf/conf44/cf44_9.pdf.

Linsley, Philip M and Philip J. Shrives (2006), Risk reporting: A study of risk disclosures in the annual reports of UK companies, The British Accounting Review 38 (2006) hlm.387-404, available at http://www.sciencedirect.com/ science/article/pii/S0890838906000461.

MacDonald, S.Scott and Timothy W. Koch (2006), Management of Banking. Singapore: South-Western, Cengage Learning.

Mallin, Chris., Andy Mullineux and Clas Wihlborg (2004), The Financial Sector and Corporate Governance - Lessons from the UK. Center for Law, Economics, and Financial Institutions on Copenhagen Business School (CBS), LEFIC Working Paper 2004-6, available at http://openarchive.cbs.dk/bitstream/ handle/10398/6789/wplefic062004.pdf?sequence=1.

Masciandaro, Donato., Maria J. Nieto and Henriette Prast (2007), Financial Governance of Banking Supervision, Documentos de Trabajo No. 0725. Madrid: Banco De Espana, available at http://www.bde.es/f/webbde/SES/ Secciones/Publicaciones/PublicacionesSeriadas/DocumentosTrabajo/07/Fic/dt 0725e.pdf.

Oorschot, Laura Van (2009), Risk reporting: An Analysis of the German Banking Industry. Erasmus University Rotterdam, School of Economics, Master Accounting, Auditing and Control, available at https://thesis.eur.nl/pub/5413/ M598-vanOorschot_294874.pdf.

Pyle, David H (1997), Bank Risk Management: Theory, Research Program in Finance-Working Paper RPF-272. Conference on Risk Management and Deregulation in Banking, Jerusalem, May 17-19, 1997, available at http://www.haas.berkeley.edu/groups/finance/WP/rpf272.pdf. 
Saunder, Anthony and Marcia Millon Cornett (2011), Financial Institutions Management: A Risk Management Approach 7ed, Singapore: McGrawHill International.

Suhardjanto, Djoko., Aryane Dewi, Erna Rahmawati and Firazonia M. (2012), Peran Corporate Governance dalam Praktik Risk Disclosure pada Perbankan Indonesia, Jurnal Akuntansi \& Auditing Volume 9/No. 1/November 2012, available at http://ejournal.undip.ac.id/index.php/akuditi/article/view/4358/ 3977.

Suhardjanto, Djoko and Aryane Dewi (2011), Pengungkapan Risiko Finansial dan Tata Kelola Perusahaan: Studi Empiris Perbankan Indonesia, Jurnal Keuangan dan Perbankan, Vol. 15, No. 1 Januari 2011, hlm 105-108, available at https://jurkubank.files.wordpress.com/2012/01/11djokosuhardjanto_encrypted. pdf.

Walsh, J.P. and J.K. Seward (1990), On the Efficiency of Internal and External of Corporate Control Mechanisms, Academy of Management Review 1990 Vol. 15 No. 3. Hlm: 421-458, available at https://www.jstor.org/stable/258017? seq=1\#page_scan_tab_contents.

Zadeh, Farahnaz Orojali and Alireza Eskandari (2012), Firm Size as Company's Characteristic and Level of Risk Disclosure: Review on Theories and Literatures, International Journal of Business and Social Science Vol. 3 No. 1, available at http://www.ijbssnet.com/journals/Vol_3_No_17_September_2012/ 2.pdf.

Zadeh, Farahnaz Orojali and Alireza Eskandari (2012), Looking Forward to Financial Risk Disclosure Practices by Malaysian Firms, Australian Journal of Basic and Applied Sciences 6 (8), available at http://ajbasweb.com/old/ajbas/2012/ August/208-214.pdf. 